\title{
Cloning and Expression of Treponema pallidum Antigens in Escherichia coli
}

\author{
By MARK J. BAILEY, † CHRISTOPHER M. THOMAS, ALAN COCKAYNE, \\ RICHARD A. STRUGNELL AND CHARLES W. PENN* \\ School of Biological Sciences, University of Birmingham, Birmingham B15 2TT, UK
}

(Received 23 January 1989; revised 7 June 1989; accepted 13 June 1989)

\begin{abstract}
A library of Treponema pallidum genomic DNA fragments produced by partial Sau3A digestion was established in Escherichia coli K12 using the plasmid vector pAT153. The library was screened using immune syphilitic rabbit serum and six recombinant phenotypes expressing eight treponemal polypeptides were detected. With two exceptions, all the recombinant gene products were the same size as polypeptides detected on Western immunoblots of T. pallidum. The genes encoding three novel gene products, with molecular masses in SDS-PAGE of 42, 17 and $15.5 \mathrm{kDa}$, which had not been cloned previously from $T$. pallidum were also identified. Monoclonal antibodies which reacted with four of the eight recombinant polypeptides were generated.
\end{abstract}

\section{INTRODUCTION}

Studies on the immunobiology and pathogenicity of Treponema pallidum subsp. pallidum, the aetiological agent of venereal syphilis, have been restricted by the inability to culture the organism in vitro. Although sensitive analytical techniques such as SDS-PAGE and Western immunoblotting have allowed detailed analysis of the polypeptide and antigenic composition of T. pallidum (reviewed by Norris et al., 1987), the significance of individual treponemal components in the stimulation of immune responses relevant to the immunopathology of syphilis infection, or as potential virulence determinants, remains unclear. Detailed analysis of such components, using conventional fractionation techniques, is technically demanding, given the limited amount of material which can be obtained by growth of $T$. pallidum in the rabbit testis (Penn, 1983).

The inability to cultivate $T$. pallidum in vitro also necessitates the use of rabbit-grown treponemes for use as antigen in routine serological tests for syphilis. Problems of specificity may arise in such assays because of the observed cross reactivity of antigens present in $T$. pallidum with those of commensal and non-pathogenic treponemes (Pedersen et al., 1980; Lukehart et al., 1982). Antibody to such cross-reactive antigens has been detected in sera of nonsyphilitic individuals (Hanff et al., 1983a). The specificity of serological tests for syphilis and their diagnostic value could be improved by the use of $T$. pallidum-specific antigens. Analysis of the humoral immune response to T. pallidum infection both in the rabbit model (Hanff et al., $1983 \mathrm{~b}$ ) and in humans (Hanff et al., 1982; Hensel et al., 1985) has identified a number of antigens of potential use in immunodiagnostic tests for syphilis. The specificity of individual antigens or antigenic determinants has also been demonstrated for some of the major T.pallidum immunogens (Bailey et al., 1987; Radolf \& Norgard, 1988).

As a possible method of circumventing problems associated with the preparation of $T$. pallidum antigens, a number of workers have used recombinant DNA technologies to produce $T$. pallidum polypeptide gene products in vitro. A limited number of treponemal antigens have been

$\dagger$ Present address: NERC Institute of Virology and Environmental Virology, Microbiology, Mansfield Road, Oxford OX1 3SR, UK.

Abbreviation: IRS, immune rabbit syphilitic serum. 
cloned and expressed in Escherichia coli (Walfield et al., 1982; Stamm et al., 1982; van Embden et al., 1983; Norgard \& Miller, 1983; Peterson et al., 1986; Hindersson et al., 1987; Hsu et al., 1988). In several instances the same polypeptide has been cloned in independent studies, e.g. an antigen of heterogeneous molecular mass of 35-28 kDa (Walfield et al., 1982; van Embden et al., 1983). A number of recombinant polypeptides have been purified from $E$. coli in sufficient quantity to allow their assessment as potential immunodiagnostics (Coates et al., 1986; Ijsselmuiden et al., 1989) or vaccinogens in the rabbit model of experimental syphilis (Borenstein et al., 1988). However, clones encoding several major immunogens of $T$. pallidum, e.g. the flagellum, have not yet been identified in $T$. pallidum recombinant DNA gene banks. We have therefore used recombinant DNA technology in an attempt to isolate additional $T$. pallidum gene products which may be of use both in the diagnosis of syphilis and in increasing understanding of the immunobiology of this disease. We describe the successful cloning and expression of five $T$. pallidum antigens which have been detected in earlier investigations, and three novel cloned antigens which have not been reported in previous studies.

\section{METHODS}

T. pallidum. The Nichols strain of $T$. pallidum subsp. pallidum was used throughout this study. T. pallidum was maintained by intratesticular passage in New Zealand White rabbits (Penn, 1983).

Genetic manipulation. All techniques were essentially as described by Maniatis et al. (1982); enzymes, media and chemicals were purchased from Gibco-BRL, Northumberland Biologicals, Pharmacia, Difco, BDH and Sigma. E. coli strain $\mathrm{HB} 101\left[\mathrm{~F}^{\prime}\right.$ hsdS20 $\left(\mathrm{r}^{-} \mathrm{B}^{-}{ }_{\mathrm{B}}\right)$ recA13 ara-14 proA 2 lac Y1 galK2 $\mathrm{rpsL} 20\left(\mathrm{Sm}^{\mathrm{T}}\right)$ xyl-5 mtl-1 supE44 $\left.\lambda^{-}\right]$was used throughout this study. The high-copy-number plasmid pAT153 (Twigg \& Sherratt, 1980) was used as the cloning vector.

Purification of T. pallidum DNA and genomic cloning. DNA was extracted from approximately $10^{10}$ cells of $T$. pallidum by SDS lysis and proteinase $\mathrm{K}$ digestion and purified by $\mathrm{CsCl}$ fractionation. The DNA was partially digested with Sau3A to an average size of $4 \mathrm{kbp}$, ligated into BamHI-digested and dephosphorylated pAT153 DNA and transformed into E. coli HB101. Recombinants were selected on the basis of tetracycline sensitivity and ampicillin resistance.

Colony and Western immunoblotting. Recombinant $\mathrm{HB} 101$ colonies were transferred by lifting onto nitrocellulose filters (Amersham) and delipidated in chloroform vapour for $5 \mathrm{~min}$. After fixing in ethanol and air-drying, the filters were incubated in $3 \%(\mathrm{w} / \mathrm{v})$ bovine serum albumin (BSA)/0.1\% $\mathrm{v} / \mathrm{v})$ Tween 20 in phosphate-buffered saline (PBS) (Penn et al., 1985) for $1 \mathrm{~h}$ at room temperature to block non-specific binding sites on the nitrocellulose. Extensive washing in PBS removed unfixed bacterial debris and the residual filter-bound material was reacted (Broome \& Gilbert, 1978) with pooled immune rabbit serum (IRS). Bound antibody was detected as described for Western immunoblotting (see below).

Western immunoblots were prepared from linear 10 or $12.5 \%(\mathrm{w} / \mathrm{v})$ acrylamide SDS-PAGE gels as described previously (Penn et al., 1985). E. coli cells expressing recombinant proteins were grown in LB broth (Maniatis $e t$ al., 1982), in the presence of $100 \mu \mathrm{g}$ ampicillin $\mathrm{ml}^{-1}$, pelleted by centrifugation and electrophoresed at a final concentration of approximately $5 \times 10^{7}$ cells per lane using the electrophoresis buffer system of Laemmli (1970). Following transfer to nitrocellulose membranes (Penn et al., 1985) Western immunoblots were reacted with IRS, $1 / 200$ dilution, for $3 \mathrm{~h}$ at room temperature. Immunoblots were washed thoroughly in PBS and bound antibody detected using second antibodies conjugated to either alkaline phosphatase ( $O^{\prime}$ Connor \& Ashman, 1982) or horseradish peroxidase (Bailey et al., 1987) and their respective substrates. Migration of polypeptides was compared with those of known molecular mass standards (Bio-Rad).

Monoclonal antibodies. Monoclonal antibodies were produced as described previously (Bailey et al., 1987). Mice were immunized with multiple injections of $T$. pallidum, the spleens removed and splenocytes fused with NS-1 myeloma cells grown in RPMI 1640 medium supplemented with $10 \%(\mathrm{v} / \mathrm{v})$ foetal calf serum. Hybrids surviving treatment with HAT were assayed for specific antibody production by ELISA. Hybridomas producing reactive supernatants were recloned by limiting dilution and expanded to produce supernatants for analysis against Western immunoblots of $T$. pallidum. Where specific monoclonal antibodies were not available, monospecific polyclonal antibody was eluted from excised regions of Western immunoblots carrying proteins transferred from SDS-PAGE gels loaded with approximately $5 \times 10^{9}$ recombinant $E$. coli, according to the method of Beall \& Mitchell (1986). Monoclonal HATR-125 was the generous gift of Dr P. Hindersson (Statens Seruminstitut, Copenhagen, Denmark).

Restriction mapping and construction of deletion derivatives. DNA from recombinant plasmids was prepared by $\mathrm{CsCl}$ centrifugation and samples containing 1-2 $\mu \mathrm{g}$ of DNA restricted with 10 units of the relevant restriction enzyme at $37^{\circ} \mathrm{C}$ for $2 \mathrm{~h}$. Digestions using $S m a \mathrm{I}$ were incubated at $30^{\circ} \mathrm{C}$. Restriction fragments were analysed on 
20-cm-long gels run in Tris/borate/EDTA buffer (Maniatis et al., 1982). In order to define more closely the regions of DNA encoding $T$. pallidum polypeptides and for use in future studies of DNA sequence analysis, recombinant plasmids were digested with appropriate restriction enzymes and religated to form deletion derivatives. Plasmid DNA isolated from these transformants was analysed by restriction mapping and antigen expression was analysed by both colony and Western immunoblotting. The following abbreviations were used for designation of deletion

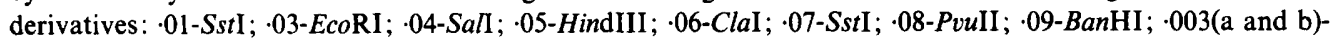
$X h o I$; and $\cdot 005(\mathrm{~b}$ and $\mathrm{c})-\mathrm{Bg} / \mathrm{II}$.

\section{RESULTS}

\section{Western immunoblot analysis of cloned antigens}

A gene bank of chromosomal $T$. pallidum DNA was constructed in $E$. coli by inserting DNA which had been partially digested with Sau3A into the restricted and dephosphorylated BamHI site of the vector pAT153. Ampicillin-resistant recombinants were identified by sensitivity to tetracycline in replica plates. The plasmid DNA from 172 randomly selected ampicillinresistant, tetracycline-sensitive recombinants was analysed by restriction-enzyme digestion. The average insert size was $4.1 \mathrm{kbp}$ (maximum $11 \cdot 6$, minimum $<1$ ). Colonies were screened initially by blotting against IRS on nitrocellulose filters. Those colonies which were reactive were picked into liquid cultures and analysed by Western immunoblotting. Six clones representative of six phenotypes which reacted positively on Western immunoblots were designated pMJB10-60 (Fig. 1, Table 1). None of the cloned polypeptides was consistently visualized in SDS-PAGE gels stained with PAGE Blue 83 (BDH) (data not shown). The gene products of pMJB10-60 were compared with $T$. pallidum polypeptides reacted in Western immunoblots with IRS. Only the gene products of pMJB10, pMJB20 and pMJB60 could be classified under the system of Norris et al. (1987) (Table 1). With the exception of that encoded by pMJB40, all the recombinant polypeptides were essentially equivalent in SDS-PAGE mobility to those produced in $T$. pallidum. (Minor differences in mobility of approximately $1 \mathrm{kDa}$ were detected between the recombinant 37 and $42 \mathrm{kDa}$ polypeptides expressed by pMJB10 and pMJB20 respectively and the respective $T$. pallidum polypeptides.) In the screening of approximately 14500 colonies (considered to be a representative $T$. pallidum gene bank) some of the six phenotypes were detected a number of times. The phenotype pMJB10 (44.5/37 kDa antigens) was detected most often (six times).

Table 1. Designation of polypeptides encoded by PMJB10-60 according to Norris et al. (1987) and previous reports of repeated cloning of $T$. pallidum polypeptide antigens

\begin{tabular}{|c|c|c|c|c|}
\hline \multirow[b]{2}{*}{ Plasmid } & \multicolumn{2}{|c|}{ Molecular mass (kDa) } & \multirow{2}{*}{$\begin{array}{c}\text { Norris } \\
\text { classification* }\end{array}$} & \multirow{2}{*}{$\begin{array}{c}\text { Previous cloning } \\
\text { (Reference } \dagger \text { and strategy } \ddagger)\end{array}$} \\
\hline & E. coli & $T$. pallidum & & \\
\hline pMJB10 & $44 \cdot 5$ & $44 \cdot 5$ & Protein $\mathbf{g}$ & $1^{a}$ \\
\hline pMJB10 & 37 & $36 \S$ & Unclassified & $1^{a}$ \\
\hline pMJB20 & 42 & 41 & Protein h & None \\
\hline pMJB30 & $29-35$ & $29-35$ & Unclassified & $1^{a}, 2^{b}, 3^{a}$ \\
\hline pMJB40 & 29 & 35 & Unclassified & $1(\mathrm{TmpC})^{a}$ \\
\hline pMJB50 & $24-28$ & $24-28$ & Unclassified & $1(\mathrm{TpE})^{a}$ \\
\hline pMJB60 & 17 & $16 \cdot 5$ & Unclassified & None \\
\hline pMJB60 & $15 \cdot 5$ & $15 \cdot 5$ & Protein $\mathrm{p}$ & None \\
\hline \multicolumn{2}{|c|}{$\begin{array}{l}\text { Other recombinant } \\
\text { antigens }\end{array}$} & $\begin{array}{l}47 \\
190\end{array}$ & $\begin{array}{l}\text { Protein } \mathrm{f} \\
\text { Protein a }\end{array}$ & $\begin{array}{l}4^{c}, 5^{c}, 7^{a} \\
6^{a}, 3^{a}\end{array}$ \\
\hline
\end{tabular}

* Only those polypeptides which could be stained with Coomassie Blue were classified by Norris et al. (1987).

† Reference: 1, van Embden et al. (1983); 2, Swancutt et al. (1986); 3, Hindersson et al. (1986); 4, Norgard et al. (1986); 5, Peterson et al. (1986); 6, Fehniger et al. (1984); 7, Hindersson \& Bangsdorg (1987).

$\ddagger$ Cloning strategy: $a$, Sau3A partial digestion; $b$, BamHI partial digestion; $c$, AluI/HaeIII partial digestion.

$\S$ Only weakly reactive on a Western immunoblot. 


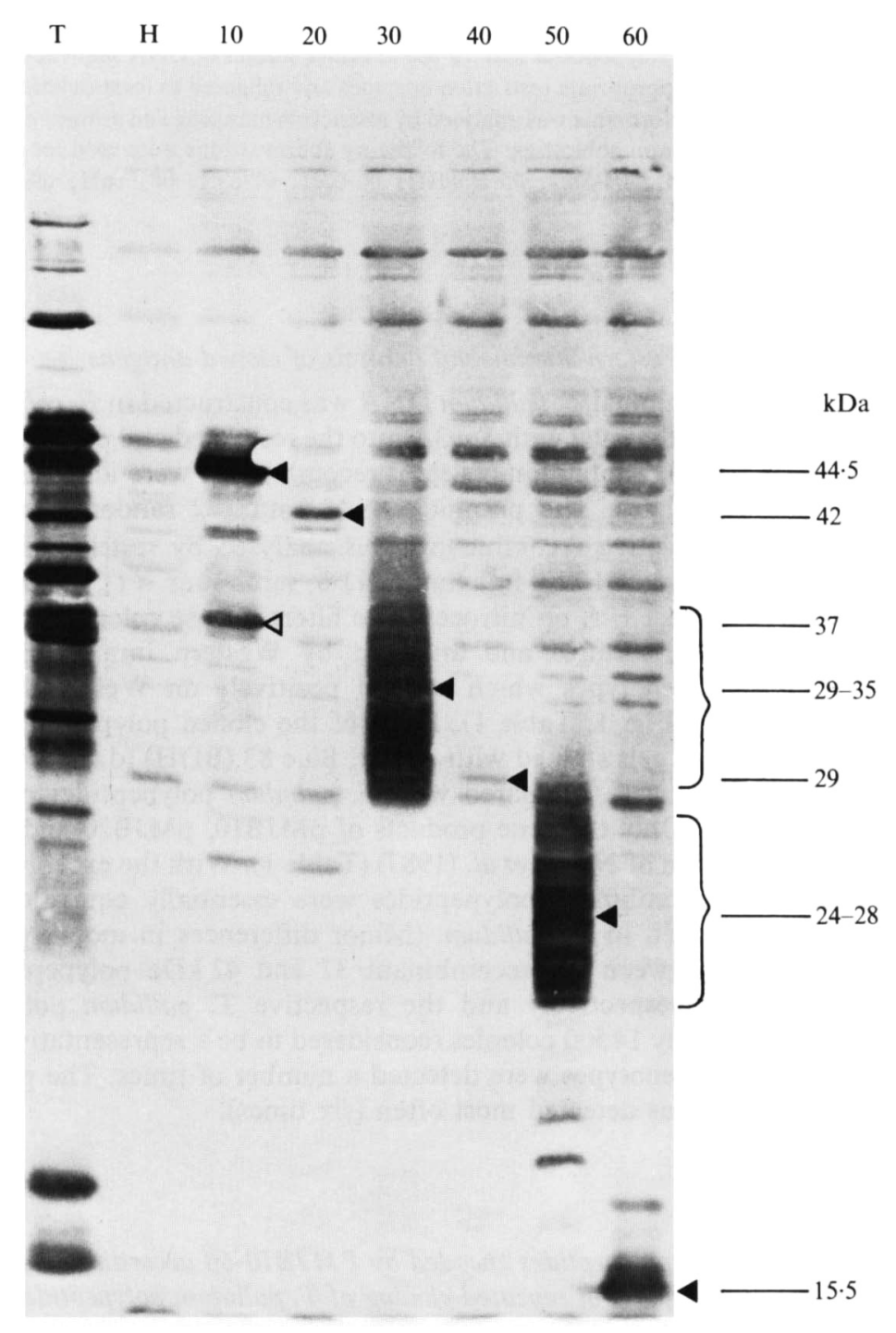

Fig. 1. Western immunoblot of antigens expressed by pMJB10-60. Cell proteins from overnight cultures of $E$. coli $\mathrm{HB} 101(\mathrm{H})$ containing plasmids pMJB10-60 (10-60) were separated by SDS-PAGE and transferred to nitrocellulose membrane. Antigen profiles, detected by reaction with IRS, were compared with $T$. pallidum $(\mathrm{T})$ and $E$. coli $\mathrm{HB} 101(\mathrm{H})$. Treponemal antigens expressed by recombinant plasmids are arrowed, and their molecular masses indicated by $\mathrm{kDa} . \triangleleft$ and $\triangleleft$ denote products of cloned genes.

\section{Reaction with monoclonal antibodies and construction of deletion derivatives}

pMJB10 encoded two polypeptides of 44.5 and $37 \mathrm{kDa}$ (Fig. $2 a$ ). The larger polypeptide reacted with monoclonal antibody 2B11 (Fig. $2 b$ ). No hybridoma producing monoclonal antibody reactive with the lower-molecular-mass protein was detected in screenings of cell fusions. The restriction map of pMJB10 shows a high degree of similarity with that of pRIT4694 of Hansen et al. (1985), where two proteins of 44.5 and $36.5 \mathrm{kDa}$, designated TmpA and TmpB were found to be expressed by a $2 \cdot 4 \mathrm{kbp} \mathrm{T}$. pallidum DNA fragment (coordinates 5.9-2.4, Fig. $2 c$ ). Sequence analysis of the TmpA gene (data not shown) revealed that the gene possessed a signal peptide which was encoded downstream from the SmaI site in Fig. 2 (c) (coordinate 5.9) 


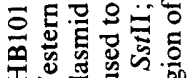
3 可要

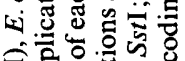

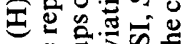

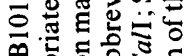

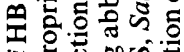
实产.

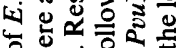
कि 西

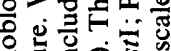

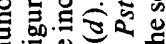

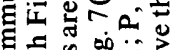
自 我 证 की

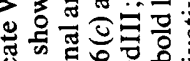

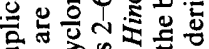

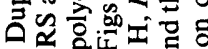

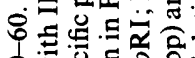
0 论

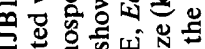
$\sum \overline{0}$

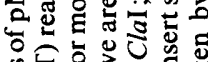

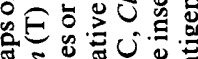
สำ. ธิ

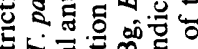

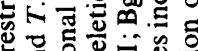

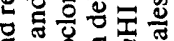
○ิ 잉혀

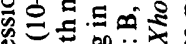

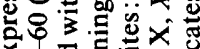
×웡

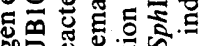

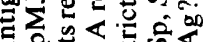
<

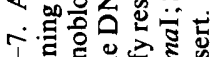

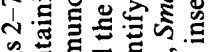

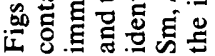

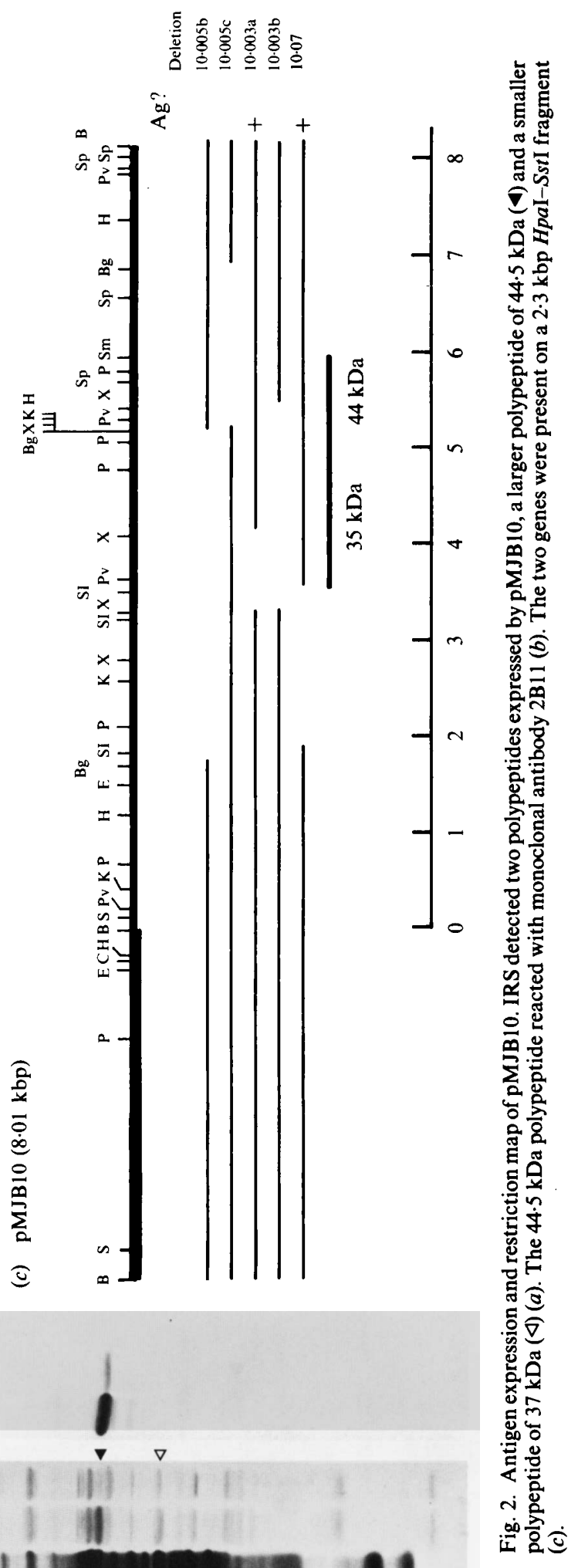




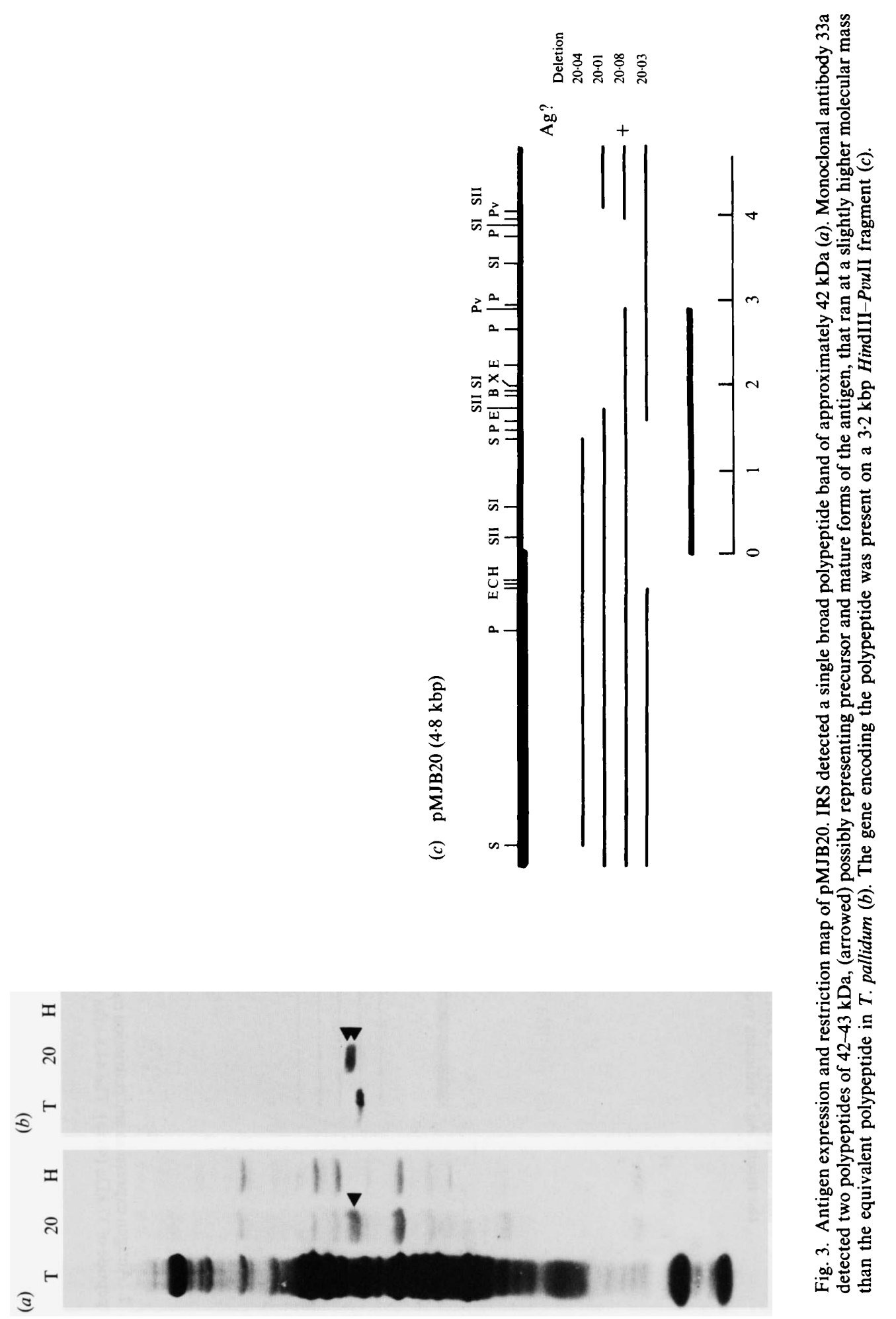


(Hansen et al., 1985). Monoclonal antibody 2B11 reacted with the TmpA gene product of Hansen et al. (1985) (data not shown), confirming that the larger gene product encoded by pMJB10 was the same as that described as TmpA. In this study, the TmpB protein was truncated by deletion of an XhoI fragment (coordinates 4.1-3.2) suggesting that the $C^{\prime}$-terminus of the $37 \mathrm{kDa}$ protein fell between these two XhoI sites (Fig. $2 c$ ). DNA sequence analysis of subclones containing the Bg/II fragment (coordinates 6.7-5.2) (data not shown) confirmed the identity between regions of pMJB10 and pRIT4600, the recombinant plasmid of Hansen et al. (1985) which encodes TmpA and TmpB (unpublished observations).

\section{Analysis of pMJB20}

pMJB20 encoded a single polypeptide of $42 \mathrm{kDa}$ in Western immunoblots reacted with IRS (Fig. $3 a$ ). Reactivity with monoclonal antibody $33 \mathrm{a}$ resolved the gene product into a doublet, suggesting that the protein was initially translated with a signal peptide (Fig. $3 b$ ). The molecular mass of the $E$. coli product was approximately $1 \mathrm{kDa}$ larger than the equivalent protein in $T$. pallidum. Restriction endonuclease analysis and characterization of deletion derivatives of pMJB20 mapped the gene to a $2.9 \mathrm{kbp}$ region of DNA which fell between HindIII and PvuII sites (coordinates $0 \cdot 0-2 \cdot 9$, Fig. $3 c$ ).

\section{Analysis of pMJB30}

The gene product of pMJB30 was a diffuse band of molecular mass $28-34 \mathrm{kDa}$ (Fig. $4 a$ ). Monoclonal antibody $10 \mathrm{c}$, which also recognizes the treponemal protein TpD (Norris et al., 1987) (data not shown) reacted with the gene product of pMJB30. Restriction mapping and analysis of deletion derivatives of pMJB30 (Fig. $4 c$ ) revealed that the activity of the gene was retained on a $1.6 \mathrm{kbp}$ HindIII-BamHI fragment (coordinates 2.6-4.2) (Fig. 4c). The similarity between the restriction maps of pMJB30 and two other plasmids known to encode an antigen of similar molecular mass and electrophoretic characteristics - pRIT3200 (van Embden et al., 1983; Hindersson et al., 1986) and pMN20 (Swancutt et al., 1986) - suggests that the polypeptide cloned in all three studies is identical.

\section{Analysis of pMJB40}

The recombinant plasmid pMJB40 encoded a single polypeptide of $29 \mathrm{kDa}$ (Fig. $5 a$ ). Monoclonal antibody 15 recognized both the $29 \mathrm{kDa}$ pMJB40 polypeptide in $E$. coli as well as a larger polypeptide of $35 \mathrm{kDa}$ in $T$. pallidum (Fig. $5 b$ ). It has been shown (S. J. Norris, unpublished observations) that this monoclonal antibody reacts with an antigen known as TmpC, cloned previously by van Embden et al. (1983). The reduced molecular mass of the pMJB40 gene product in $E$. coli suggests that the gene has been truncated at the $C^{\prime}$-terminus during cloning. From analysis of deletion derivatives of pMJB40 (Fig. $5 c$ ), it would appear that the gene encoding the $35 \mathrm{kDa} T$. pallidum polypeptide probably contains a Sau3A site at coordinate 0.0 (Fig. $5 c$ ) which was cleaved during partial digestion of the treponemal DNA prior to ligation into the vector pAT153. Termination of translation of the truncated gene in the recombinant $E$. coli must be provided by an in-phase termination codon present in the vector. No restriction map of pRIT9000, the plasmid encoding TmpC (J. D. van Embden, personal communication), has been published so comparisons with the restriction map of pMJB40 have not been made. It is probable, however, that pMJB40 contains a fragment of $T$. pallidum DNA, the cloning of which was reported by van Embden et al. (1983).

\section{Analysis of pMJB50}

The plasmid pMJB50 encoded a gene product of heterogeneous molecular mass (24-28 kDa, Fig. $6 a$ ) that was similar in Western blot appearance to the gene product of pMJB30. The monoclonal antibody HATR-125 (Norris et al., 1987) reacted with this gene product giving an identical profile to that seen with IRS (Fig. 6b). Norris et al. (1987) reported that this monoclonal also reacts with the polypeptide designated $\mathrm{TpE}$ described by van Embden et al. (1983). Restriction mapping and analysis of deletion derivatives revealed that the gene was 


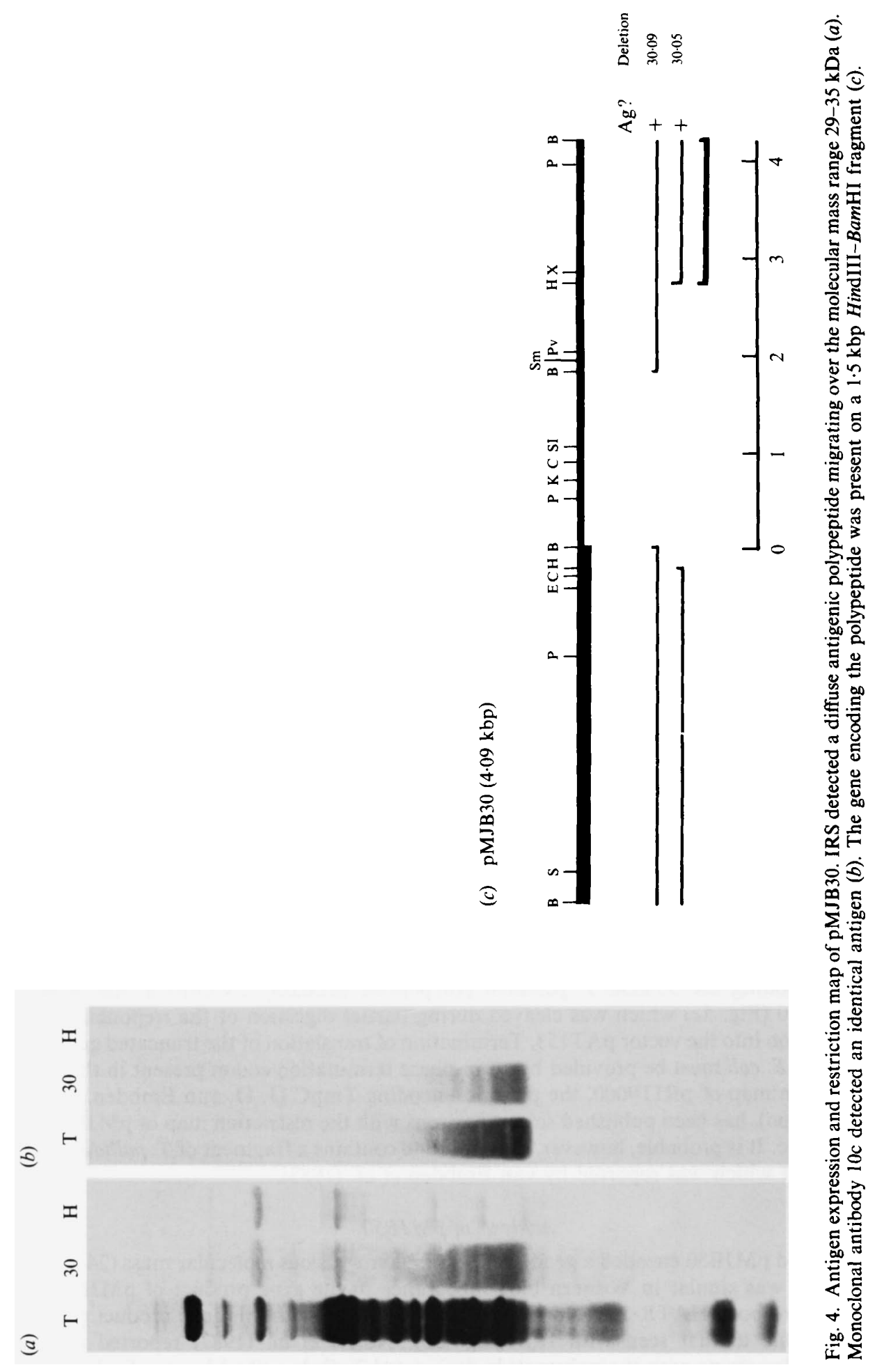




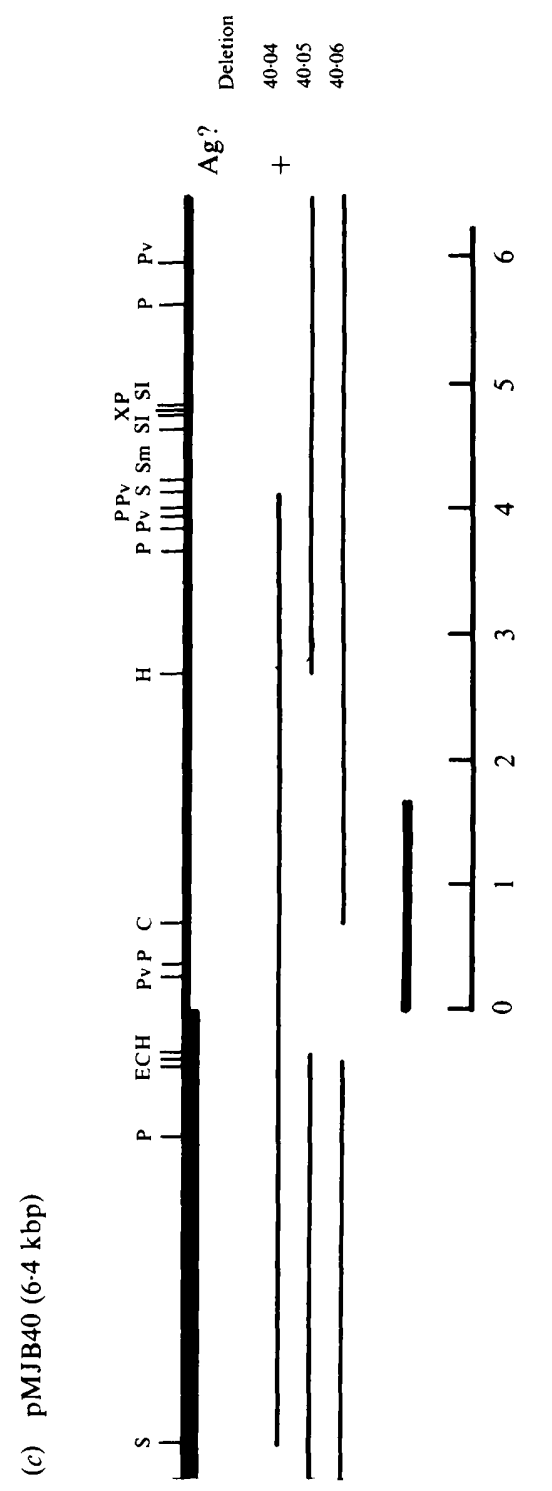

능 을 更家 政 政 몽 可语 要要要 这势 然 氙 S. 을 포옹옹 敋密 ำ 四 สิ 츨 .0 合总

올 을 ํํㅇㅎㅇ 过泀

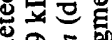
भुई

光 웡중 吅试 $\sum_{0}$ a 농용

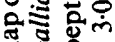
송 낭형

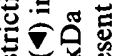

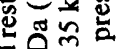
옳 둔 음 동

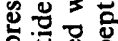
혀ㅇㅝㅠㅇ

2 总宫吉 ส <远告 n 的造造 


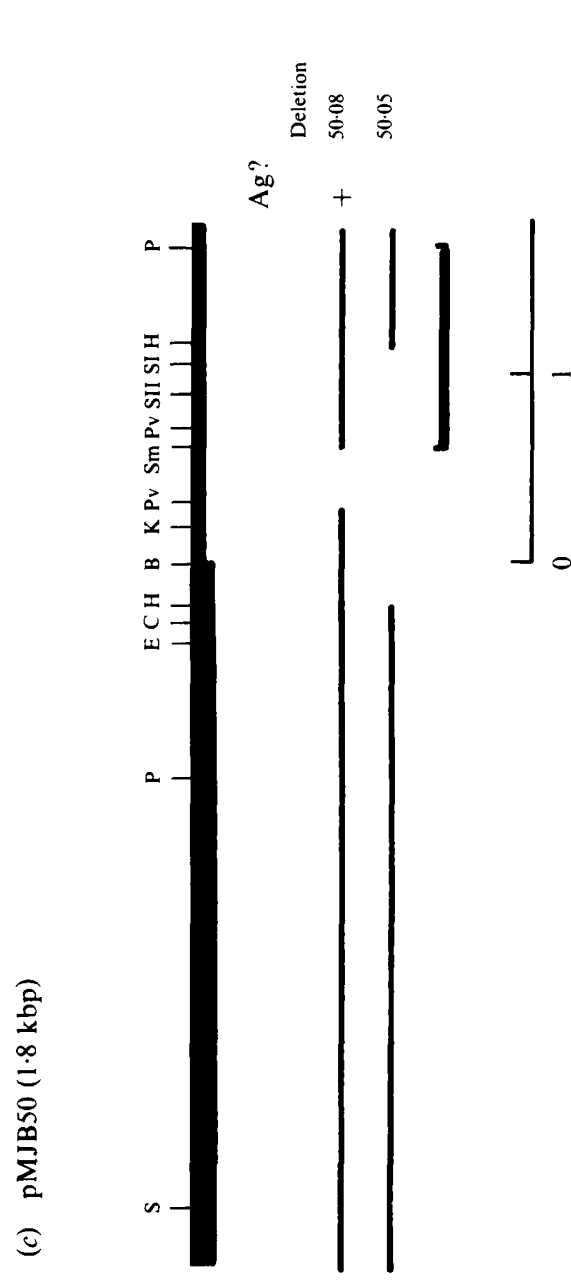

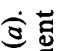

跑

กิ

จิ

离

尊高

용

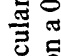

홍

I

n

$2^{1}$

I

i

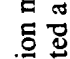



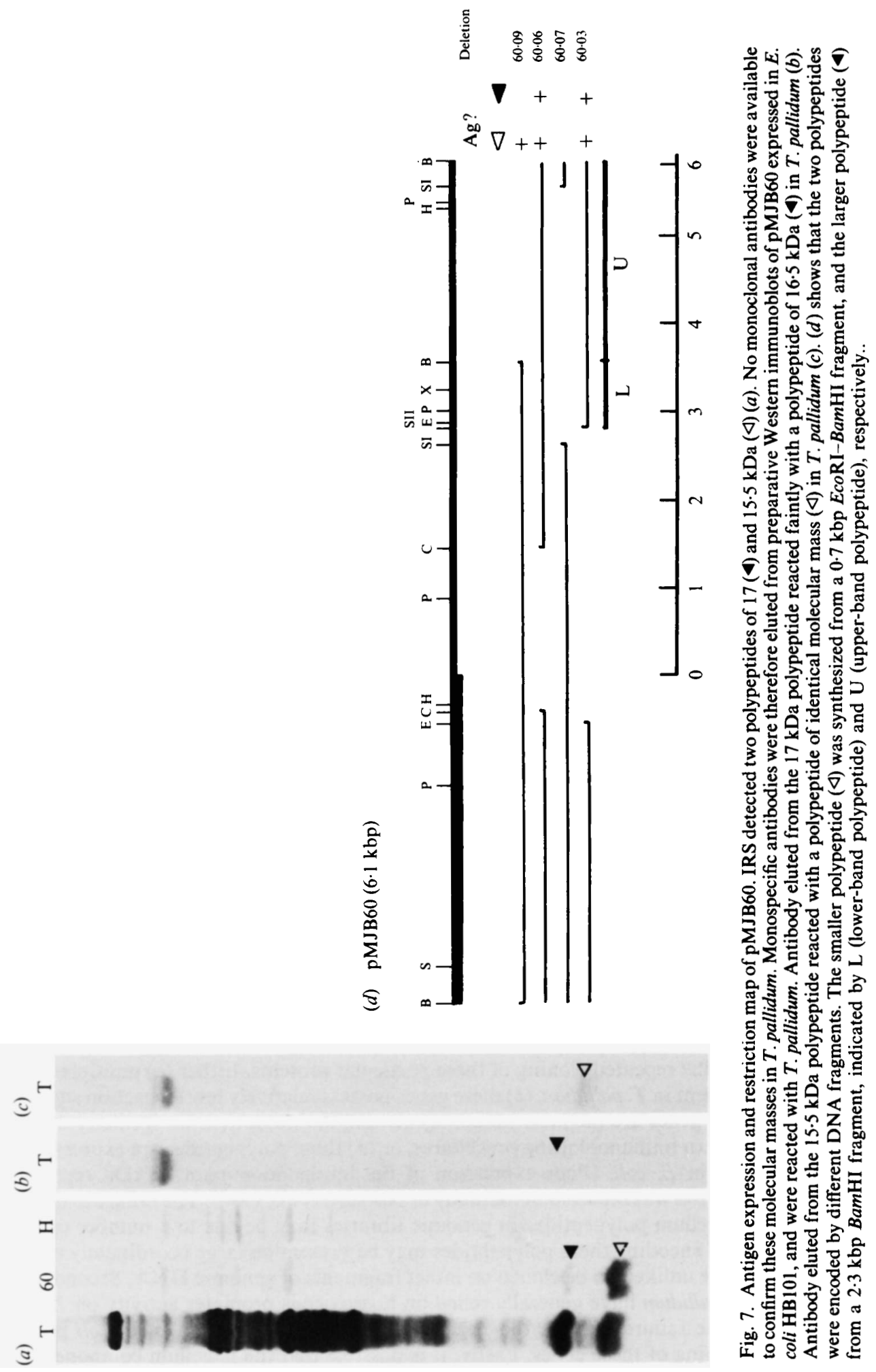
present on a $1 \cdot 1 \mathrm{kbp}$ PvuII-PstI fragment (coordinates 0.6-1·7, Fig. $6 c$ ). No restriction map of pRIT7100, the plasmid encoding TpE (van Embden et al., 1983) has been published for comparison with that of pMJB50.

\section{Analysis of pMJB60}

Plasmid pMJB60 encoded two polypeptides of 17 and $15.5 \mathrm{kDa}$ (Fig. $7 a$ ). The larger polypeptide was only weakly antigenic, whereas the smaller protein reacted strongly with IRS. None of the monoclonal antibodies available reacted with either of these proteins. Antibody eluted from preparative Western immunoblots of the larger polypeptide reacted weakly with an antigen of $16.5 \mathrm{kDa}$ in $T$. pallidum (Fig. $7 \mathrm{~b}$ ). Antibody similarly eluted from the smaller polypeptide reacted strongly with the $15.5 \mathrm{kDa}$ polypeptide of similar appearance in $T$. pallidum (Fig. $7 c$ ). Analysis of deletion derivatives of pMJB60 showed that the two polypeptides were synthesized independently (Fig. $7 d$ ). Deletion of the $2.1 \mathrm{kbp} \mathrm{BamHI}$ fragment (coordinates 3.65.7) resulted in loss of expression of the larger polypeptide but retained expression of the smaller polypeptide. The smaller polypeptide was mapped to a $800 \mathrm{bp}$ EcoRI-BamHI fragment (coordinates $2 \cdot 8-3 \cdot 6$, Fig. $7 d$ ).

\section{DISCUSSION}

Infection with $T$. pallidum elicits a high titre humoral immune response to a large number of treponemal polypeptides (Hanff et al., 1982; Hensel et al., 1985), a response which is exploited in the serodiagnosis of syphilis. Among the most immunogenic of these polypeptides are the major flagellum polypeptide of $37 \mathrm{kDa}$ and a putative outer-membrane protein of $47 \mathrm{kDa}$ (Hanff et al., 1982, 1983 b; Lukehart et al., 1982; Jones et al., 1984). The $47 \mathrm{kDa}$ polypeptide has been cloned (Norgard et al., 1986; Peterson et al., 1986; Hindersson \& Bangsdorg, 1987). This polypeptide is considered to be $T$. pallidum-specific (Radolf \& Norgard, 1988) and the immunodiagnostic potential of responses to this antigen have recently been demonstrated in cases of congenital syphilis (Sanchez et al., 1989). Cross-reactive and specific antigenic determinants have been identified by the use of monoclonal antibodies on the $37 \mathrm{kDa}$ flagellum-associated polypeptides of T. pallidum (Bailey et al., 1987; Cockayne et al., 1987). Such T.pallidum-specific determinants could be exploited as reagents in serodiagnostic tests and one of the major aims of the present study was to try to isolate recombinants expressing this polypeptide from $T$. pallidum gene banks. The failure to isolate such recombinants may be due to a number of possible reasons which are considered below.

Several independent investigators have now successfully cloned polypeptides from $T$. pallidum into $E$. coli (Walfield et al., 1982; Stamm et al., 1982; van Embden et al., 1983; Norgard \& Miller, 1983; Peterson et al., 1986; Hsu et al., 1988). All have used restriction enzymes to produce partial digests of chromosomal DNA. Despite differences in vectors and restriction enzymes employed, the total number of cloned treponemal polypeptides is relatively small. While genes encoding several minor antigens have been detected in genomic libraries, those for a number of very immunogenic proteins have yet to be found. The polypeptides that have been cloned in two or more independent studies are shown in Table 1. There are several possible explanations for the repeated cloning of these particular proteins. Either (a) multiple copies of the genes are present in $T$. pallidum, $(b)$ these genes possess relatively few restriction sites, $(c)$ the products of these genes are the most immunogenic and maintain their antigenicity during the colony and Western immunoblotting procedures, or $(d)$ these polypeptides are expressed better than any others in $E$. coli. (Poor expression of the immunodominant $47 \mathrm{kDa}$ recombinant polypeptide in E. coli was reported in the study of Norgard et al., 1986). The failure to detect, for example, the flagellum polypeptides in genomic libraries may be due to a number of factors. Firstly, the genes encoding these polypeptides may be present on large coordinately expressed operons which are unlikely to be cloned on intact fragments of genomic DNA. Secondly, genes cloned from $T$. pallidum have generally relied on homologous promoter activity on $E$. coli for detection, and the failure of, e.g., the flagellum promotors to function in $E$. coli may have hindered the cloning of these genes. Lastly, it is possible that the flagellum components of $T$. 
pallidum, if expressed, may be toxic for the $E$. coli host, although a recent report of the successful cloning of a Spirochaeta aurantia flagellum gene (Brahamsa \& Greenberg, 1988) would suggest that this may not be the case. Some of the problems encountered in producing fully representative, expressed $T$. pallidum DNA may be alleviated by using mechanically sheared DNA cloned into expression vectors to generate genomic libraries, and oligonucleotide probes derived from $N$-terminal amino acid sequences of targetted proteins in their subsequent screening.

Despite the observed limitations on cloning targetted genes from $T$. pallidum, the cloned polypeptides that are available should assist studies on the pathogenesis and immunology of syphilis. Several treponemal antigens have been proposed as having a functional role in the development of immunity against T.pallidum (Strugnell et al., 1986; Bailey et al., 1987). Among these proteins is the $44.5 \mathrm{kDa}$ protein expressed by pMJB10 (Fig. 1, Table 1). To date, none of the proteins found in 'membrane' extracts of $T$. pallidum has been assessed for their ability to protect against syphilis infection. Apart from the flagellum-associated polypeptides, and the $60 \mathrm{kDa} T$. pallidum common antigen (Hindersson et al., 1987), no functional role has been definitely assigned to any polypeptides in $T$. pallidum. Recombinant DNA technology should assist the investigation of the assembly of treponemal proteins into membranes and study of their potential functions, for example as porins.

\section{REFERENCES}

Bailey, M. J., Cockayne, A. \& Penn, C. W. (1987). Monoclonal antibodies directed against surfaceassociated polypeptides of Treponema pallidum define a biologically active antigen. Journal of General Microbiology 133, 1793-1803.

BeAll, J. A. \& Mitchell, G. F. (1986). Identification of a particular antigen from a parasite cDNA library using antibodies affinity purified from selected portions of Western blots. Journal of Immunological Methods 86, 217-233.

Borenstein, L. A., Radolf, J. D., Fehniger, T. E., Blanco, D. R., Miller, J. N. \& Lovett, M. A. (1988). Immunization of rabbits with recombinant Treponema pallidum surface antigen 4D alters the course of experimental syphilis. Journal of Immunology 140, 2415-2421.

Brahamsha, B. \& GreEnberg, E. P. (1988). Immunoelectron microscope analysis of Spirochaeta aurantia periplasmic flagella and molecular cloning of a major axial filament antigen. Abstracts of the Annual Meeting of the American Society for Microbiology, p. 193.

BROOME, W. S. \& GILBERT, W. (1978). Immunological screening method to detect specific translation products. Proceedings of the National Academy of Sciences of the United States of America 75, 27462749.

Coates, S. R., Sheridan, P. J., Hansen, D. S., Laird, W. J. \& ERLICH, H. A. (1986). Serospecificity of a cloned protease-resistant Treponema pallidumspecific antigen expressed in Escherichia coli. Journal of Clinical Microbiology 133, 1397-1407.

Cockayne, A., Bailey, M. J. \& Penn, C. W. (1987). Analysis of sheath and core structures of the axial filament of Treponema pallidum. Journal of General Microbiology 133, 1397-1407.

VAN EMbden, J. D., van DER Donk, H. J., van EIJK, R. V., VAN DER HeIDE, H. G., DE JoNG, J. A., VAN Olderen, M. F., Osterhaus, A. D. \& Schouls, L. M. (1983). Molecular cloning and expression of
Treponema pallidum DNA in Escherichia coli $\mathrm{K}-12$. Infection and Immunity 42, 187-196.

Fehniger, T. E., Walfield, A. M., Cunningham, T. M., Radolf, J. D., Miller, J. N. \& LovetT, M. A. (1984). Purification and characterization of a cloned protease-resistant Treponema pallidum specific antigen. Infection and Immunity 46, 598607.

Hanff, P. A., Fehniger, T. E., Miller, J. N. \& LOVETT, M. A. (1982). Humoral immune response in human syphilis to polypeptides of Treponema pallidum. Journal of Immunology 129, 1287-1291.

HanfF, P. A., Miller, J. N. \& LovetT, M. A. (1983a). Molecular characterisation of common treponemal antigens. Infection and Immunity 40, 825-828.

HanfF, P. A., Bishop, N. H., Miller, J. N. \& Lovett, M. A. $(1983 b)$. Humoral immune response in experimental syphilis to polypeptides of Treponema pallidum. Journal of Immunology 131, 1973-1977.

Hansen, E. B., Pedersen, P. E., Schouls, L. M., SeVerin, E. \& van Embden, J. D. A. (1985). Genetic characterization and partial sequence determination of a Treponema pallidum operon expressing two immunogenic membrane proteins in Escherichia coli. Journal of Bacteriology 162, 1227-1237.

Hensel, U., Jobst-Wellensiek, H. \& Bhakd, S. (1985). Sodium dodecyl sulphate-polyacrylamide gel electrophoresis immunoblotting as a serological tool in the diagnosis of syphilitic infections. Journal of Clinical Microbiology 21, 82-87.

Hindersson, P. \& BANGsDorF, J. (1987). Cloning and expression of 4 Treponema pallidum antigens identified by monoclonal antibodies. Abstracts of the Annual Meeting of the American Society for Microbiology, D47, p. 79.

Hindersson, P., COCKayne, A., Schouls, L. M. \& VAN EMBDEN, J. D. A. (1986). Immunochemical characterization and purification of Treponema pallidum antigen TpD expressed by Escherichia coli K-12. Sexually Transmitted Diseases 13, 237-244. 
Hindersson, P., Knudsen, J. D. \& Axelsen, N. H. (1987). Cloning and expression of Treponema pallidum common antigen (Tp-4) in Escherichia coli $\mathrm{K} 12$. Journal of General Microbiology 133, 587-596.

Hsu, P.-L., QIN, M., Norris, S. J. \& Sell, S. (1988). Isolation and characterization of recombinant $E s$ cherichia coli clones secreting a 24-kilodalton antigen of Treponema pallidum. Infection and Immunity 56, 1135-1143.

Ijsselmuiden, O. E., Schouls, L. M., Stolz, E., Aelbers, G. N. M., Agterberg, C. M. \& VAN EMBDEN, J. D. A. (1989). Sensitivity and specificity of an enzyme linked immunosorbent assay using the recombinant DNA-derived Treponema pallidum protein TmpA for serodiagnosis of syphilis and the potential use of TmpA for assessing the effect of antibiotic therapy. Journal of Clinical Microbiology 27, 152-157.

Jones, S. A., Marchitto, K. S., Miller, J. N. \& NorgARD, M. A. (1984). Monoclonal antibody with haemagglutination, immobilization, and neutralization activities defines an immunodominant, 47,000 mol. wt., surface-exposed immunogen of Treponema pallidum (Nichols). Journal of Experimental Medicine 160, 1404-1420.

LAEMMLI, U. K. (1970). Cleavage of structural proteins during the assembly of the head of bacteriophage T4. Nature, London 227, 680-685.

Lukehart, S. A., BaKer-Zander, S. A. \& Gubish, E. R. (1982). Identification of Treponema pallidum antigens: comparison with a non-pathogenic treponeme. Journal of Immunology 129, 833-838.

Maniatis, T., Fritsch, E. F. \& SambrooK, J. (1982). Molecular Cloning: A Laboratory Manual. Cold Spring Harbor NY: Cold Spring Harbor Laboratory.

Norgard, M. V., Chamberlain, N. R., Swancutt, M. A. \& Goldberg, M. S. (1986). Cloning and expression of the major 47 -kilodalton surface immunogen of Treponema pallidum in Escherichia coli. Infection and Immunity 54, 500-506.

Norgard, M. V. \& Miller, J. N. (1983). Cloning and expression of Treponema pallidum (Nichols) antigen genes in Escherichia coli. Infection and Immunity 42, 435-445.

Norris, S. J., Alderete, J. F., Axelsen, N. H., Bailey, M. J., Baker-Zander, S. A., Baseman, J. B., Bassford, P. J., Baughn, R. E., Cockayne, A., Hanff, P. A., Hindersson, P., Larsen, S. A., LovetT, M. A., Lukehart, S. A., Miller, J. N., Moskophidis, M. A., Muller, F., Norgard, M. V., Penn, C. W., Stamm, L. V. van Embden, J. D. \& WiChER, K. (1987). Identity of Treponema pallidum subsp. pallidum polypeptides: correlation of sodium dodecyl sulphate-polyacrylamide gel electrophoresis results from different laboratories. Electrophoresis 8, 77-92.

O'Connor, C. G. \& Ashman, L. K. (1982). Applica- tion of nitrocellulose transfer techniques and alkaline phosphatase-conjugated anti-immunoglobulin for determination of the specificity of monoclonal antibodies to protein mixtures. Journal of Immunological Methods 54, 267-271.

Pedersen, N. S., Axelsen, N. H., Jorgensen, B. B. \& Petersen, C. S. (1980). Antibodies in secondary syphilis against five of forty Reiter treponeme antigens. Scandinavian Journal of Immunology 11, 629-633.

PENN, C. W. (1983). The use of the rabbit as a model for syphilis infection. In Experimental Bacterial and Parasitic Infections, pp. 145-151. Edited by G. Keusch \& T. Wadstrom. Amsterdam: Elsevier Biomedical.

Penn, C. W., Cockayne, A. \& Bailey, M. J. (1985). The outer membrane of Treponema pallidum: biological significance and biochemical properties. Journal of General Microbiology 131, 2349-2357.

Peterson, K. M., Baseman, J. B. \& Alderete, J. F. (1986). Isolation of a Treponema pallidum gene encoding immunodominant outer envelope protein P6, which reacts with sera from patients at different stages of syphilis. Journal of Experimental Medicine 164, 1160-1170.

Radolf, J. D. \& Norgard, M. V. (1988). Pathogen specificity of $T$. pallidum subsp. pallidum membrane proteins identified by phase partitioning with Triton $\mathrm{X}-114$. Infection and Immunity 56, 1825-1828.

Sanchez, P. J., McCracken, G. H. JR, Wendel, G. D., Olsen, K., Threlkeld, N. \& Norgard, M. V. (1989). Molecular analysis of the fetal IgM response to Treponema pallidum antigens: implications for improved serodiagnosis of congenital syphilis. Journal of Infectious Diseases 159, 508-517.

Stamm, L. V., Folds, J. D. \& Bassford, P. J., JR. (1982). Expression of Treponema pallidum antigens in Escherichia coli $\mathrm{K}-12$. Infection and Immunity 36, 1238-1241.

Strugnell, R. A., Williams, W. F., Drummond, L. P., Pedersen, J. S., Toh, B. H. \& Faine, S. (1986). Development of increased seroblot reactivity against a 45,000 dalton polypeptide of Treponema pallidum (Nichols) correlates with the establishment of chancre immunity in syphilitic rabbits. Infection and Immunity 51, 957-960.

Swancutt, M. A., Twehous, D. A. \& Norgard, M. V. (1986). Monoclonal antibody selection and analysis of a recombinant DNA-derived surface immunogen of Treponema pallidum expressed in Escherichia coli. Infection and Immunity 52, 110-119.

Twigg, A. J. \& SherratT. D. J. (1980). Transcomplementable copy-number mutants of plasmid ColE1. Nature, London 283, 216-218.

Walfield, A. M., HanfF, P. A. \& Lovett, M. A. (1982). Expression of Treponema pallidum antigens in Escherichia coli. Science 216, 522-523. 